\title{
Effect of Corrosion in the CS Operation Indoors of the Electronics Industry in the Northwest of Mexico
}

\author{
Efecto de la corrosión en la operación de SC en interiores de \\ la industria electrónica del noroeste de México
}

\author{
López-Badilla G. \\ Cybernetic and Electronic Department \\ Researcher and in Corrosion and Materials \\ CETYS, Mexicali, BC \\ E-mail: glopezbadilla@yahoo.com \\ Vega-Matus A. \\ Students of Cybernetic and Electronic Engineering \\ CETYS, Mexicali, BC \\ E-mail:av2311@hotmail.com \\ Millán-Arce D. \\ Students of Cybernetic and Electronic Engineering \\ CETYS, Mexicali, BC \\ E-mail:dm2010@hotmail.com
}

\author{
González-Kleyton J. \\ Students of Cybernetic and Electronic Engineering \\ CETYS, Mexicali, BC \\ E-mail:jgz1200@gmail.com \\ Contreras-León G. \\ Students of Cybernetic and Electronic Engineering \\ CETYS, Mexicali, BC \\ E-mail:gc5455@gmail.com
}

Information on the article: received: June 2011, accepted: December 2011

\begin{abstract}
The electronics industry is an important factor in Mexico's economy, representing $80 \%$ of companies in the northwest of this country, where we find Mexicali (as arid zone) and Tijuana (as marine region), two cities in the state Baja California, adjacent to cities in California, USA, on the border of Mexico-United States. A study was conducted indoors in three plants of each city mentioned above, to determine if corrosion phenomena has an effect on the lifetime and productive performance of the CS. The results show that major air pollutants present indoors, that generate aggressive environments in Mexicali are the sulfides, while in Tijuana are the chlorides, which affect the functioning of the CS, and originate electrical failures in industrial equipments and machines.
\end{abstract}

\section{Keywords:}

- corrosion

- control systems

- climatic factors

- air pollutants 


\section{Resumen}

La industria electrónica es un factor importante en la economía de México, lo que representa $80 \%$ de las empresas instaladas en el noroeste del país, donde se encuentra Mexicali (zona árida) y Tijuana (región marina), dos ciudades del estado de Baja California colindantes con ciudades de California, EU, ubicadas en la frontera de México-Estados Unidos. En este tipo de industrias se utilizan dispositivos electrónicos llamados sistemas de control (SC) aplicados en las empresas, los cuales son fundamentales para mejorar la eficiencia en los procesos de fabricación, ya que al tener un mal funcionamiento, la economía de cualquier empresa tiene perdidas económicas. Se realizó una investigación en interiores de tres plantas en cada ciudad mencionada para determinar si la corrosión tiene un efecto en el tiempo de vida y rendimiento productivo de los SC. El fenómeno de la corrosión se presenta por variaciones de factores climáticos como la humedad y temperatura, así como por la presencia de contaminantes del aire como SO2, H2S, NOX en Mexicali y SO2, NOX y Cl-en Tijuana, los cuales sobrepasan los estándares de calidad del aire en ciertos periodos del año determinados por SEMARNAT-México y EPA-EU. Los resultados muestran que los principales contaminantes del aire presentes en interiores que generan ambientes agresivos en Mexicali son los sulfuros, mientras que en Tijuana los cloruros, que afectan el funcionamiento de los SC, con lo que se originan fallas eléctricas en equipos y maquinas de plantas industriales. La vida de los SC evaluados se redujo un $25 \%$ en presencia de corrosión y la calidad de los productos fabricados en esta zona de México disminuyó un 30\%. Esto representa pérdidas económicas a las empresas de esta región.

\section{Descriptores:}

- sistemas de control

- corrosión

- factores climáticos

- contaminantes del aire

\section{Introduction}

The electronics industry is using electronic devices called control systems (CS), which are applied in the industrial plants; they are essential for improving the efficiency of manufacturing processes, and when its have malfunctions, the economy of any company has economic losses. The phenomenon of corrosion is presented by changes in climatic factors such as humidity and temperature, and the presence of air pollutants such as $\mathrm{SO}_{2}, \mathrm{H}_{2} \mathrm{~S}$, and $\mathrm{NO}_{\mathrm{x}}$ in Mexicali, $\mathrm{SO}_{2}, \mathrm{NO}_{\mathrm{x}}$ and $\mathrm{Cl}^{-}$in Tijuana, which exceed the air quality standards set by SEMARNAT-Mexico and US-EPA, at certain times of year. Uncontrolled microclimate of industrial plants generates the corrosion process by the variations of humidity and temperature outdoors that affect indoor conditions and some air pollutants that penetrate through air-conditioning systems and small holes in buildings (López, 2008; Moncmanova, 2007). This affects the operations of CS and, therefore, the functions of industrial electronic equipments and machines. This study shows some ways to control these parameters to keep away from the presence of corrosion and have efficient operation of CS to conserve with better conditions the lifetime of CS for a long time (Veleva et al., 2008; Dillon, 2000). The life time of the CS evaluated were reduced by $25 \%$ in the presence of corrosion and the quality of products manufactured in this zone of Mexico decreased by $30 \%$. This represents economic losses to the companies in this region. The generation of corrosion in electronic devices and equipment of automobiles has been important in recent years, when the complexity of electronic systems used in electronic equipments and machines is increased to improve their efficiency.

\section{Atmospheric pollution}

Gaseous and solid airborne pollutants comprise small dust particles of hydrogen sulfide (H2S), sulfur dioxide (SO2), chloride ions ( $\mathrm{Cl}-$ ) and nitrogen oxides (NOX), which are capable of penetrating into indoor areas of 
the industrial plants through inlets of air filtering systems. These pollutants generate aggressive indoor environments in combination with humidity and temperature, producing corrosion damage of metallic components of electronic equipment. In spite of the existing corrosion prevention and protection system as well as the application of electronic industry standards, corrosion control is not easy in specific climatic regions, especially in arid and marine regions (Robertson and Fenderson, 2005; King and Mamdani, 1977). Arid zones are typical, with $\mathrm{RH}$ ranging from $30 \%$ to $90 \%$ in summer with temperatures higher than $40^{\circ} \mathrm{C}$ and winter temperatures lower than $5^{\circ} \mathrm{C}$. In marine environments, the $\mathrm{RH}$ is around $20 \%$ to $80 \%$ and temperatures during summer rise to $35^{\circ} \mathrm{C}$ and go down to $3{ }^{\circ} \mathrm{C}$ in winter. These factors, promoted by anthropogenic and natural activities facilitate the corrosion of the copper components. The corrosion of copper specimens was evaluated by the gravimetric method; it was correlated with the minimum average and maximum $\mathrm{RH}$ and outdoor temperature values in different seasonal periods, which affect the indoor climate plants. The efficiency of the electrical behavior of copper components in electronic devices is a function of the amount of humidity and pollutants present in the indoor environment (Belanger, 1995). This concerns companies for the economic losses due to defective electronic products, since it promotes rapidly the corrosion process on connectors and electrical connections and thus causing electrical failures, malfunctioning in electronic equipment and in some cases stops the manufacturing line. This brings warm temperatures, causing deterioration in some metallic materials used in the electronic connectors and connections such as copper. All this decreases the quality of the articles manufactured in this region and generates economic losses (Bishop, 1997). When variations of humidity are very drastic, several variations of temperature occur and therefore the electronic equipments and devices suffer changes in their functionality. To measure humidity ranges, it is necessary to install sensors indoors of industrial plants to be in contact with the environments.

\section{Climate factors vs electrical failures}

Electronic equipment and machines of industrial plants consist of printed circuit boards, also called e-cards. The lifetime of these electronic components is related to the type of material, operation and exposition to environment. In some cases, the durability decreases by the exposition to air pollutants and climatic factors, mainly drastic variations of humidity and temperature (Lópéz,
2008; Veleva et al., 2008; King and Mamdani, 1977). Engineering design, wrong manufacturing methods and inadequate mechanical movements generate improper installations. E-cards are constituted by a lot of electronic devices and are installed according to their operation, with sections separated with insulators to avoid electrical connections between undesirable zones (analog or digital signals), power (high and low), speed (high and low) and types of printed boards. There are a variety of electronic components, which are classified according to wave (sine, triangular, square or linear).

\section{CS operations}

Control systems automate engineering processes (CSAEP) are based on many parameters and are called programmable automation controllers (PAC). These devices have some objectives with stable signals, are robust to avoid errors, and very efficient according to a predetermined criterion avoiding sudden and unrealistic behavior (Dorf and Bishop, 2005; Lewis and Yang, 1997). The CS are necessary to process, monitor, and acquire data, store and display information to be analyzed. The CS are classified by their behavior and monitoring the variations of parameters involved in the systems, to know these in a depth objective. CS must be simple and easy to understand the operation of electronic equipments and machines for industrial plants; their output signals are related with the input signals. Mean age of a CS used in the companies analyzed was less than ten years, but most electrical, electromechanical and electronic equipments and machines with age higher than ten years are not highly efficient and generate low levels of productivity. Sometimes it is necessary to use new industrial machinery to generate the adequate yielding (Kuo, 1995; Ogata, 2002; Phillips and Harbor, 2000; Goodwin et al., 2001).

The CS are composed by electronic analog components principally, that not are protected by package systems as integrated circuits (IC) and are exposed easily to indoor aggressive environments of the electronics industry. This causes, easy and rapidly, the corrosion process in their electrical connectors and connections (ECC). Figure $1 a$ and $1 b$, show the manufacturing process and operation of the CS to detect products fabricated in the electronics industry of this region, to determine if articles manufactured are accepted or rejected and to find out if the companies have economic gain or losses. A process of insertion of electronic equipment in electronic boards (e-cards) controlled by CS in the production of television and a CS in steps are represented below. 


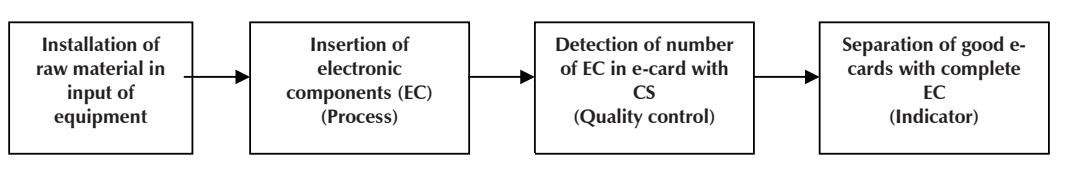

a

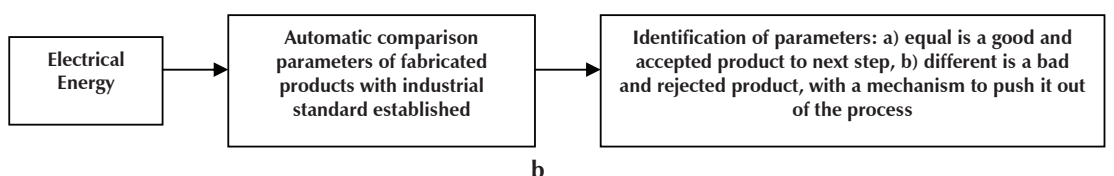

Figure 1. Block diagram of operation of electronic equipment in industrial plants: a) manufacturing process with $\mathrm{CS}$ and b) function of CS to detect good and bad products

\section{Electronics industry}

The electronics industry has grown over the past fifty years, contributing to the economy. Particularly in the State of Baja California, these companies have prospered in the industrial parks of Mexicali and Tijuana. This type of companies is installed in the principal cities of Mexico, most notably in the border with the US, specifically in the northwest. At the beginning of the industrial activities in the electronics industry, the manufacturing process was used to control variables with manual operations and in later times, CS were designed and produced to improve the industrial process, and to obtain better yielding and reduce the errors. The use of CS was a change that revolutionized the industrial machinery and the research activities indoors of the electronics industry (Lopez et al., 2007, 2010; Cole and Paterson, 2004; Annual book ASTM, 2000; ASHRAE, 1999; Lopez et al., in press). In the $20^{\text {th }}$ century, the use of these devices was very important for innovation, and in our times the goal to follow is to produce new CS at micro and nano scales, applied in aeronautic, biomedicine and spatial and telecommunications.

\section{Industrial plants in Mexicali and Tijuana}

In the electronics industry of Mexicali and Tijuana, there are a variety of devices and electronic equipment inside the plants which generate big quantities of products sold in areas around the country and the world. Three of four companies in this city produce or have electronic systems in their manufacturing process, belonging to the Assembly Plants Association (APA, 2010).

\section{Cost vs productivity}

Manufacturing plants work every day to reduce costs and increase productivity. CS cover the majority of requirements in the industrial process, replacing labor for CS, reducing the human error and costs (ISO, 1992,
$2005,2006)$. With the incorporation of this technology, control process in real time, development of complex strategies, production suggestion and important management decisions are the everyday life of the companies. In each implementation of CS, it's necessary to evaluate costs and benefits, the financial support is applied in the areas with major economical retribution.

\section{Adaptive control systems (ACS)}

This system is capable to modify the behavior as a transformation of their signals altered by the functions or external disturbances as close loop system (CLS). Analysis with different equations and block diagrams shows the functions step by step, indicating the relation of the parts of the electronic equipments and machines (Quiang and Wen, 2006). In the five companies evaluated this type of CS are installed with feedback steps to adapt the changes generated by internal o external signals, with design by analysis (detecting and modifying the main characteristics) and by synthesis (evaluating the changes and generating news in real time).

\section{Matlab software}

MATLAB is a numerical computing environment and programming language, which was created by Math Works and allows easy matrix manipulation, creation of graphs of functions and data, implementation of algorithms, creation of user interfaces between operations and other programs in different languages (Balachandran, 2005). One advantage of the use of CS with specialized software, such as MatLab, is being able to predict the performance of any industrial process and the operation of products manufactured. The data was evaluated using this software to determine in real time the industrial process and improve it for the future parameters of manufacturing operations. Linear regression analyses were performed to get the best fit models for experimental data and the trend of better yielding. 


\section{Experimental}

Electronic equipments and machines of industrial plants controlled by small devices as control systems have better yielding. In this study, the use of CS and the probability to suggest in a short period of time the use in micro and nanotechnology, was analyzed (Zlatev et al., 2009; Sankara et al., 2007; Valdez and Schorr, 2006; Lopez et al., 2010).

\section{Corrosion testing}

Copper specimens for corrosion testing were exposed at indoor conditions of electronics plants for a period of two years in Mexicali and Tijuana. The specimens corrosion was evaluated according to the ASTM standards G 1, G 4, G 31 (Annual book of ASTM, 2000), and correlated with the minimum, average and maximum outdoor $\mathrm{RH}, \mathrm{TOW}$ and temperature parameters (ISO, 1992). Also the Sulfatation Plate Technique (TPS) (ASTM, 2010) was applied in Mexicali, as well as TPS and the wet candle methods (WCM) (ASTM, 2008) in Tijuana; the electronic plants in Tijuana are located in industrial parks, while in Ensenada, plants are located at distances ranging from $1 \mathrm{~km}$ to $10 \mathrm{~km}$ from the sea shore. Rectangular specimens with dimensions of 2.5 $\mathrm{cm} \times 1 \mathrm{~cm} \times 0.5 \mathrm{~cm}$ were cleaned by immersion in an isopropyl alcohol ultrasound bath for 15 minutes. Immediately after cleaning the copper specimens, they were placed in sealed plastic bags, ready to be installed in the test indoor sites. After each exposure period the specimens were removed, cleaned and weighed to obtain the weight loss and to calculate the corrosion rates (ISO, 2005). The corrosion products morphology was examined with an optical microscope. The most active gases are hydrogen sulfide $\left(\mathrm{H}_{2} \mathrm{~S}\right)$ and $\mathrm{SO}_{x} \cdot \mathrm{H}_{2} \mathrm{~S}$ is a corrosive and toxic pollutant which originates from $\mathrm{mu}-$ nicipal sewage (ISO, 2006).

\section{CS age in electronics industry}

Analysis of using time of electronics equipments and machinery in the electronics industry of this city was made in relation to their production yielding. The major industrial process evaluated showed efficient operations with the use of CS, increasing the quantity of products with less mistakes. This study indicates that use of obsolete electromechanical and electronic machinery with CS is a very productive systems and companies have opportunity to economically support the improvement of each equipment and machine (López, 2008).

\section{Mathematical simulation}

A mathematical correlation was made in MatLab software (Duncan et al, 2005) to determine the corrosion levels (CL) indoors of electronics industry in Mexicali and Ensenada. With this analysis the deterioration grade (DG) of metallic probes of copper was found, correlating the climate factors (humidity and temperature), airs pollutants $\left(\mathrm{CO}, \mathrm{NO}_{2}, \mathrm{O}_{3}\right.$ and $\left.\mathrm{SO}_{2}\right)$ from outdoor sources that penetrate by inlets or air-conditioning systems to the interior of industrial plants, and corrosion rate (CR). Models were developed to simulate industrial processes with MatLab software. This represents the difference of using or not CS with signals indicating the levels of productivity and errors.

\section{Microscopy analysis}

Electrical connections and connectors of copper of CS were analyzed by Scanning Electron Microscopy (SEM) to determine the aggressive agents that react with the copper surface (Veleva et al., 2008; Lopez et al., 2010). For evaluation of the corrosion effect on the metals, weight loss measurements were performed. Following the weight loss determination, the corroded metallic specimens were subjected to chemical cleaning to remove the corrosion products from the surface, degreased with ethanol in an ultrasonic bath for $5 \mathrm{~min}$ and weighed. All results presented in this study are averages of triplicate specimens. The corroded specimens were analyzed by scanning electron microscopy coupled to an electron dispersive X-ray analyzer (SEM EDS, Phillips XL ESEM). X-ray diffraction (XRD) analysis of the corrosion products and their evolution in time was performed using Siemens D 5000 diffractometer with $\mathrm{Cu} \mathrm{Ka}$ monochromatic radiation (López, 2008; Lopez, et al., 2007).

\section{Results and discussion}

The control of industrial processes is fundamental in manufacturing operations to save economical funds and improve the electronic machinery used in industrial plants. This study shows an important relation that suggests companies of this region should install ACS in their industrial operations.

\section{Operation analysis of CS}

An analysis of productive yielding was made to find the differences of using new and old control systems. This information is shown in diverse evaluations as 1 to 
5 (Table 1), 5 to 10 (Table 2) and more then 10 years (Table 3) of age of CS used in three functions, indicating the percentage in each operations. In table 1 the productive yielding is higher than $80 \%$ in all activities and in the three companies in the cities evaluated, being to 1 to 5 years of CS age. This is because the ECC are not affected completely by the corrosion. In Table 2 , the range of percentages is from $60 \%$ to $70 \%$, with same characteristics of Table 1, of 5 to 10 years of age, indicating that ECC suffer a partial deterioration by corrosion, and Table 3 shows the percentages under $50 \%$ in all conditions mentioned above about the correlation of productive yielding and CS age, representing the full deterioration of ECC, after more then 10 years of operation.

Other factors analyzed were economic, technical and health parameters with old and new control sys- tems, to determine the productive yielding related with the efficiency, costs, organization of industrial processes and technical support. The information in Table 4 represents better conditions to save costs with good efficiency, less consumption of electrical light and space occupied of CS as advantages; and less problematic situations of use new CS respect to technical operations for use of operations manual correctly and accidents occurred by ignorance of the operation of new control systems as disadvantages.

The Table 5, shows the same characteristics of Table 4 , with the use of old control systems, indicating less efficiency, most consumption of electrical light and space occupied by CS, and more severe problematic situations with technical operations without operations manual, and this originated manufacturing processes unsafe, which generated more accidents in workers.

\begin{tabular}{lcccccc}
\hline & \multicolumn{3}{c}{ Mexicali Companies } & \multicolumn{3}{c}{ Tijuana Companies } \\
\multicolumn{1}{c}{ Equipments with CS } & $\mathbf{1}$ & $\mathbf{2}$ & $\mathbf{3}$ & $\mathbf{1}$ & $\mathbf{2}$ & $\mathbf{3}$ \\
\hline Separating machine of EC & 84 & 82 & 86 & 87 & 89 & 90 \\
Machine insertion of EC & 82 & 81 & 85 & 87 & 84 & 86 \\
Tester machine operation EC & 84 & 86 & 82 & 82 & 88 & 86 \\
\hline
\end{tabular}

\begin{tabular}{ccccccc}
\hline & \multicolumn{3}{c}{ Mexicali Companies } & \multicolumn{3}{c}{ Tijuana Companies } \\
Equipments with CS & $\mathbf{1}$ & $\mathbf{2}$ & $\mathbf{3}$ & $\mathbf{1}$ & $\mathbf{2}$ & $\mathbf{3}$ \\
\hline Separating machine of EC & 63 & 60 & 64 & 68 & 69 & 66 \\
Machine insertion of EC & 62 & 65 & 67 & 63 & 68 & 64 \\
Tester machine operation EC & 64 & 66 & 61 & 68 & 64 & 67 \\
\hline
\end{tabular}

\begin{tabular}{ccccccc}
\hline & \multicolumn{4}{c}{ Mexicali Companies } & \multicolumn{3}{c}{ Tijuana Companies } \\
Equipments with CS & $\mathbf{1}$ & $\mathbf{2}$ & $\mathbf{3}$ & $\mathbf{1}$ & $\mathbf{2}$ & $\mathbf{3}$ \\
\hline Separating machine of EC & 56 & 59 & 54 & 57 & 59 & 53 \\
Machine insertion of EC & 57 & 52 & 55 & 56 & 53 & 59 \\
Tester machine operation EC & 56 & 58 & 53 & 57 & 59 & 57 \\
\hline
\end{tabular}

\begin{tabular}{lcccccc}
\hline \multicolumn{1}{c}{ Use of New CS } & \multicolumn{3}{c}{ Mexicali Companies } & \multicolumn{3}{c}{ Tijuana Companies } \\
\hline \multicolumn{1}{c}{ Advantages } & $\mathbf{1}$ & $\mathbf{2}$ & $\mathbf{3}$ & $\mathbf{1}$ & $\mathbf{2}$ & $\mathbf{3}$ \\
\hline Efficiency & 92 & 90 & 92 & 94 & 91 & 95 \\
Consumption of electrical light & 52 & 50 & 53 & 51 & 53 & 54 \\
Space occupied in machine & 25 & 27 & 21 & 26 & 23 & 20 \\
& & & & & & \\
\hline \multicolumn{1}{c}{$\quad$ Disadvantages } & $\mathbf{1}$ & $\mathbf{2}$ & $\mathbf{3}$ & $\mathbf{1}$ & $\mathbf{2}$ & $\mathbf{3}$ \\
\hline Cost & 77 & 68 & 72 & 70 & 65 & 68 \\
Technical operations & 56 & 60 & 59 & 54 & 50 & 57 \\
Accidents & 3 & 5 & 3 & 2 & 3 & 1 \\
\hline
\end{tabular}

Table 4. Analysis of use new CS in 2010, \% 


\begin{tabular}{lcccccc}
\hline \multicolumn{1}{c}{ Use of New CS } & \multicolumn{3}{c}{ Mexicali Companies } & \multicolumn{3}{c}{ Tijuana Companies } \\
\hline \multicolumn{1}{c}{ Advantages } & $\mathbf{1}$ & $\mathbf{2}$ & $\mathbf{3}$ & $\mathbf{1}$ & $\mathbf{2}$ & $\mathbf{3}$ \\
\hline Efficiency & 67 & 62 & 67 & 68 & 62 & 66 \\
Consumption of electrical light & 88 & 83 & 81 & 87 & 84 & 80 \\
Space occupied in machine & 57 & 52 & 59 & 50 & 54 & 55 \\
& & & & & & \\
\hline \multicolumn{1}{c}{ Disadvantages } & $\mathbf{1}$ & $\mathbf{2}$ & $\mathbf{3}$ & $\mathbf{1}$ & $\mathbf{2}$ & $\mathbf{3}$ \\
\hline Cost & 89 & 83 & 88 & 85 & 83 & 80 \\
Technical operations & 78 & 84 & 87 & 80 & 77 & 75 \\
Accidents & 8 & 11 & 10 & 8 & 10 & 7 \\
\hline
\end{tabular}

Table 5. Analysis of use old CS in 2010, \%

\section{MatLab simulation}

Numerical analysis was made to determine the correlation of the average of fabricated products of three industrial plants in booth cities mentioned above, and the ranges of humidity and temperature at indoor conditions in the electronics industry. Figure 2 shows the minimum productivity with values of $\mathrm{RH}$ from $15 \%$ to $45 \%$ and temperatures less than $10^{\circ} \mathrm{C}$, while the maximum productive yielding was in values of $\mathrm{RH}$ higher of $80 \%$ with temperatures from $20^{\circ} \mathrm{C}$. Figure 3 shows too the minimum productivity with values of RH from $30 \%$ to $60 \%$ and temperatures higher to $15^{\circ} \mathrm{C}$, and the maxi- mum productive yielding was in values of $\mathrm{RH}$ near to $90 \%$ with temperatures less than $20^{\circ} \mathrm{C}$. At low $\mathrm{RH}$ and temperature values, is formed a invisible thin film of water and occur the electrochemical process in some areas of ECC, and the corrosion rate (CR) was low, generating pitting corrosion, and at high $\mathrm{RH}$ and temperature ranges, the corrosion was high and, occurring uniform corrosion and deteriorate rapidly the ECC. The mathematical equation which evaluated the climate factors and air pollutants that increase the corrosion rate, is described as:

$f(x)=2 / 3 x^{3}-1 / 2 x^{2}+3 / 5 x-5 / 6$

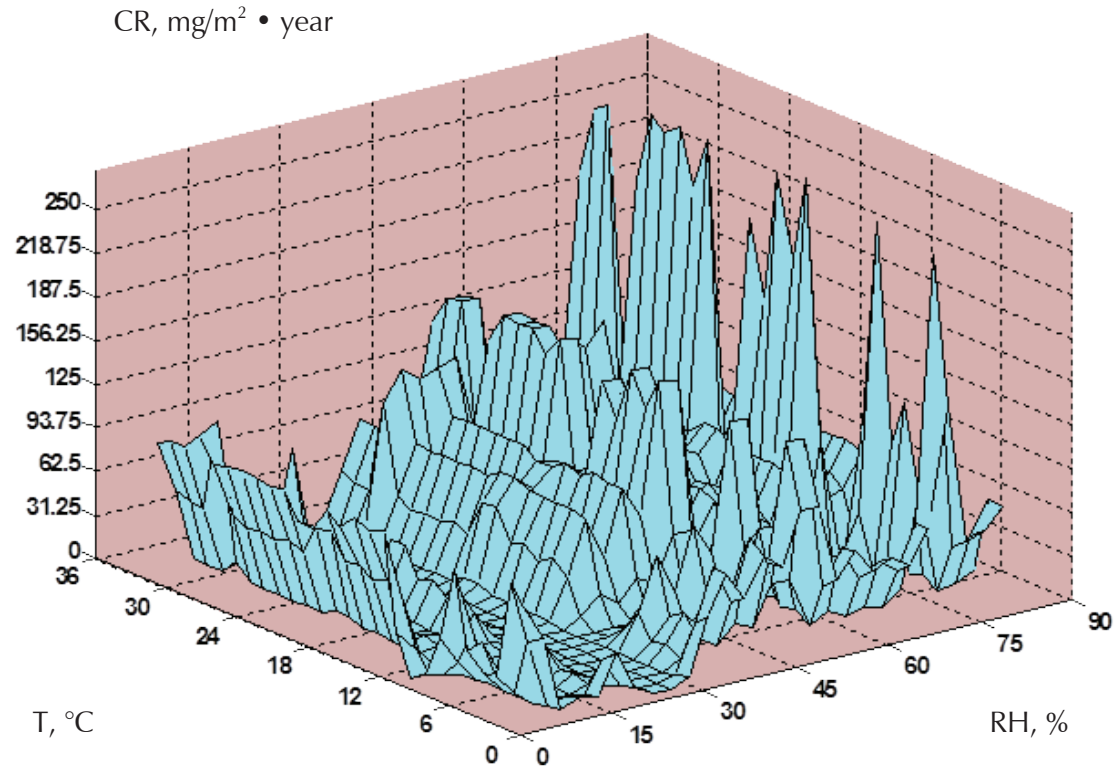

Figure 2. Correlation analysis of $\mathrm{RH}$, temperature and manufactured products by hour in one year with new CS in a company in Mexicali (2010) 


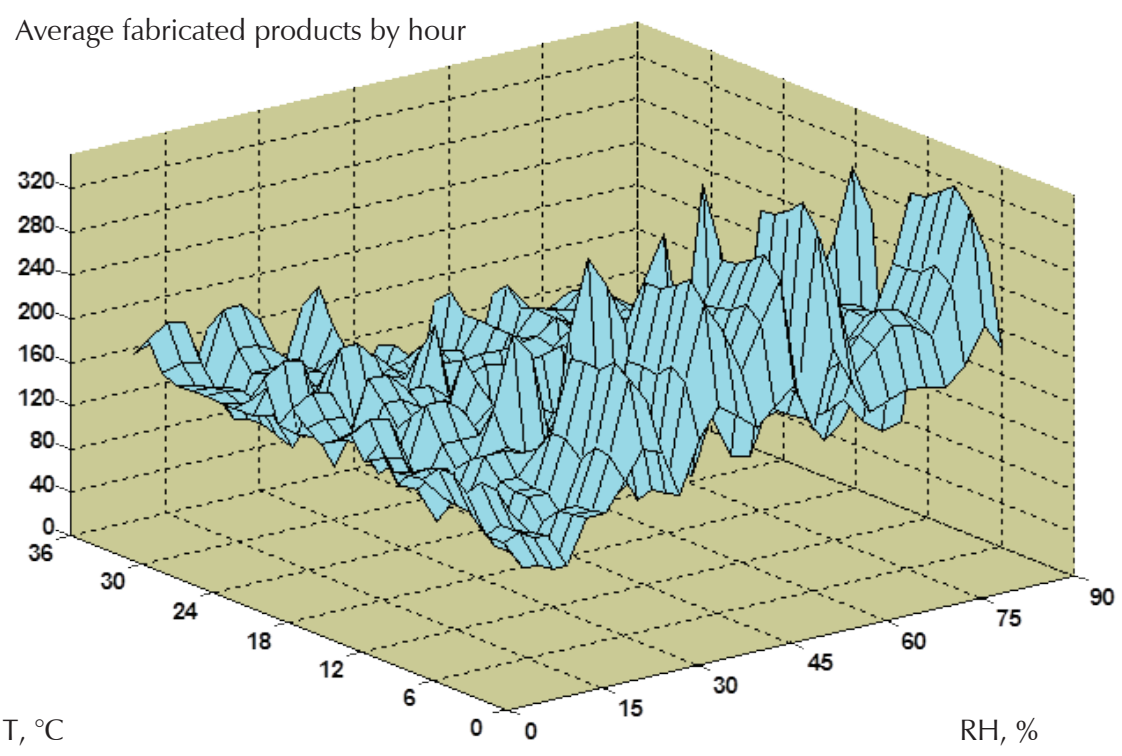

Figure 3. Correlation analysis of $\mathrm{RH}$, temperature and manufactured products by hour in one year with new CS in a company in Tijuana (2010)

\section{Influence of climate factors and air pollutants on CR}

The values of $\mathrm{RH}$ and temperature were higher than $70 \%$ and $35^{\circ} \mathrm{C}$ during the year in Mexicali and with a minimum of $20 \%$ and $30^{\circ} \mathrm{C}$ in the periods of hot desert winds (early winter and spring) and maximum of $80 \%$ and $10^{\circ} \mathrm{C}$ in the rest of the year in the Tijuana area. High levels of humidity and elevated temperature accelerated the rate of corrosion. In summer the corrosion rate was higher after six months in Mexicali and for this reason the evaluation was also made for six months in Tijuana. For temperatures in the range from $25^{\circ} \mathrm{C}$ to $35^{\circ} \mathrm{C}$, and $\mathrm{RH}$ level of $30 \%$ to $70 \%$, the corrosion rate was very high. Furthermore, in winter, at temperatures around $15^{\circ} \mathrm{C}$ to $25^{\circ} \mathrm{C}$ and $\mathrm{RH}$ levels from $35 \%$ to $75 \%$, water condensates on the metal surface and the copper corrosion rates increases very fast. Variations of relative humidity in the range from $30 \%$ to $80 \%$ and temperatures from $0^{\circ} \mathrm{C}$ to $35^{\circ} \mathrm{C}$, and concentrations of air pollutants such as sulfides in arid zones and chloride in marine environments, exceeding the permitted levels for air quality standards, are also an important condition that favors corrosion. Table 6 shows the correlation between copper and the air pollutants; $\mathrm{SO}_{2}, \mathrm{NO}_{x}$ and $\mathrm{O}_{3}$, the principal climate factors ( $\mathrm{RH}$ and temperature), concentration level of pollution and the corrosion rate (CR) at Mexicali city conditions, as a simulation in MatLab. $\mathrm{SO}_{2}$ was the air pollutant with major corrosion effect; in the winter season. The CR arises the highest value $\left(283 \mathrm{mg} / \mathrm{m}^{2}\right.$. year) when the $\mathrm{RH}$, temperature and the concentration of sulfur dioxide values are $84.2 \%, 28.2^{\circ} \mathrm{C}$ and $0.52 \mathrm{ppm}$, respectively.

\begin{tabular}{|c|c|c|c|c|c|c|c|c|c|c|c|c|}
\hline \multirow{2}{*}{$\begin{array}{l}\text { Climate } \\
\text { factors }\end{array}$} & \multicolumn{4}{|c|}{ Sulphur dioxide $\left(\mathrm{SO}_{2}\right.$} & \multicolumn{4}{|c|}{ Nitrogen oxides $\left(\mathrm{NO}_{\mathrm{x}}\right)$} & \multicolumn{4}{|c|}{ Ozone $\left(\mathrm{O}_{3}\right)$} \\
\hline & $\mathrm{RH}^{\mathrm{a}}$ & $\mathrm{T}^{\mathrm{b}}$ & $\mathrm{C}^{\mathrm{c}}$ & $\mathrm{CR}^{\mathrm{d}}$ & $\mathrm{RH}^{\mathrm{a}}$ & $\mathrm{T}^{\mathrm{b}}$ & $\mathrm{C}^{\mathrm{c}}$ & $\mathrm{CR}^{\mathrm{d}}$ & $\mathrm{RH}^{\mathrm{a}}$ & $\mathrm{T}^{\mathrm{b}}$ & $\mathrm{C}^{\mathrm{c}}$ & $\mathrm{CR}^{\mathrm{d}}$ \\
\hline \multicolumn{13}{|l|}{ Spring } \\
\hline Max & 67.6 & 38.3 & 0.15 & 189 & 78.3 & 26.3 & 0.43 & 189 & 56.7 & 27.9 & 0.28 & 179 \\
\hline Min & 26.7 & 16.4 & 0.07 & 134 & 39.1 & 15.7 & 0.25 & 112 & 29.3 & 17.2 & 0.17 & 133 \\
\hline \multicolumn{13}{|l|}{ Summer } \\
\hline Max & 89.4 & 41.5 & 0.13 & 208 & 78.9 & 42.7 & 0.52 & 186 & 78.6 & 43.2 & 0.46 & 189 \\
\hline Min & 39.3 & 23.6 & 0.10 & 188 & 37.9 & 25.6 & 0.18 & 138 & 38.3 & 24.5 & 0.21 & 153 \\
\hline \multicolumn{13}{|l|}{ Winter } \\
\hline Max & 84.2 & 28.2 & 0.52 & 283 & 81.2 & 22.6 & 0.85 & 199 & 91.2 & 30.33 & 0.72 & 192 \\
\hline Min & 28.4 & 19.7 & 0.24 & 192 & 32.7 & 11.2 & 0.27 & 158 & 46.7 & 16.9 & 0.35 & 168 \\
\hline
\end{tabular}

Table 6. Correlation of CR with climate factors in Mexicali (2010), $\mathrm{mg} / \mathrm{m}^{2} \bullet$ year

\footnotetext{
${ }^{\mathrm{a}} \mathrm{RH}$. Relative Humidity $(\%), \quad{ }^{\mathrm{b}} \mathrm{T}$. Temperature $\left({ }^{\circ} \mathrm{C}\right)$ ${ }^{c} \mathrm{C}$. Concentration Level of Air Pollutant (ppm), ${ }^{\mathrm{d}} \mathrm{CR}^{-}$Corrosion rate $\left(\mathrm{mg} / \mathrm{m}^{2}\right.$.year)
} 


\section{Microscopy examination}

SEM analyses were carried out to determine the corrosion products formed in the copper surface. Figure 4a shows scanning electron micrograph (SEM) in Mexicali, and Figure $4 \mathrm{~b}$ in Tijuana; images of areas selected covered by the principal corrosion products which are rich in chlorides for Tijuana test results and sulfides for the Mexicali specimens. The SEM analysis of $\mathrm{Cu}$ specimens was generated, it shows an analysis of the chemical composition of the thin films formed in the $\mathrm{Cu}$ specimens installed in industrial plants in both cities the surface analysis is shown. These air pollutants generate aggressive environments indoors of the electronics industry and react with ECC. In contrast to outdoor exposure, in an indoor environment the wet film on the metal surface is thinner and it is often governed by relatively constant controlled humidity conditions. Sometimes the indoor environment temperature and $\mathrm{RH}$ are contro-

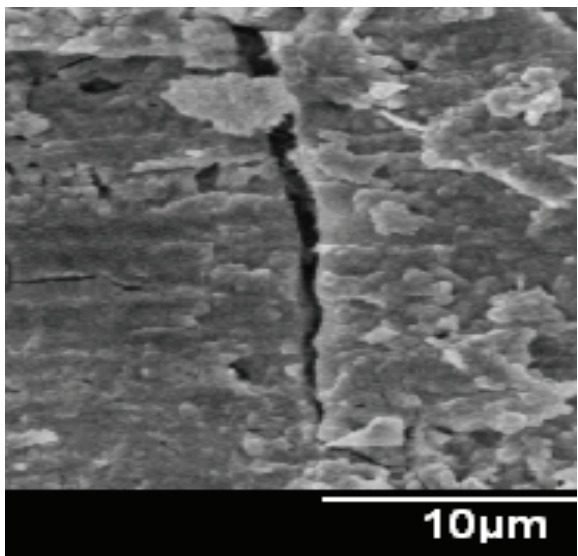

lled and as a consequence, the amount of adsorbed water on surfaces is minimal and is constrained within reasonably tight limits.

\section{AES examination}

AES analyses were carried out to determine the corrosion products formed in the CS installed in the electronics industry of Mexicali and Tijuana. The Auger spectra of ECC was generated using a $5 \mathrm{keV}$ electron beam, which shows an analysis of the chemical composition of thin films formed in the ECC of CS (Figure 5). The AES spectrum shows the surface analysis of three points which represents the different zones of ECC. The peaks of steel appear between $180 \mathrm{eV}$, finding the sulfides. The chemical composition in the both analysis was reveled, with different concentrations of chloride, sulfur, carbon, nitrogen, oxygen, which damage the copper surface.

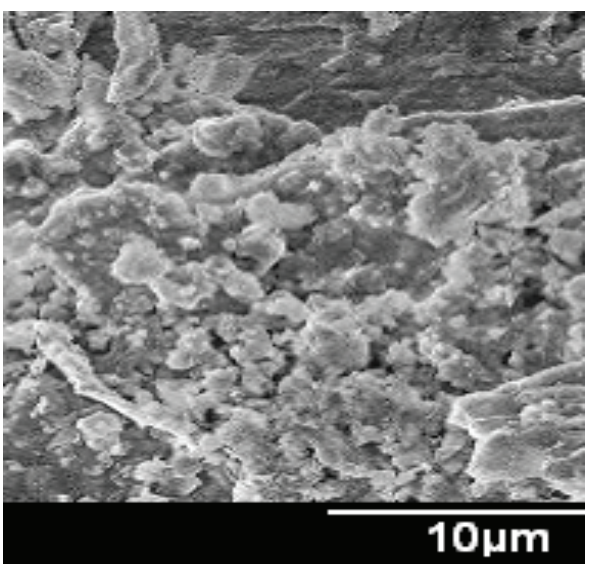

Figure 4. SEM analysis at 10X of corrosion products in electrical connectors and connections of CS with one year exposed to aggressive environments in (a) Mexicali and (b) Tijuana (2010)

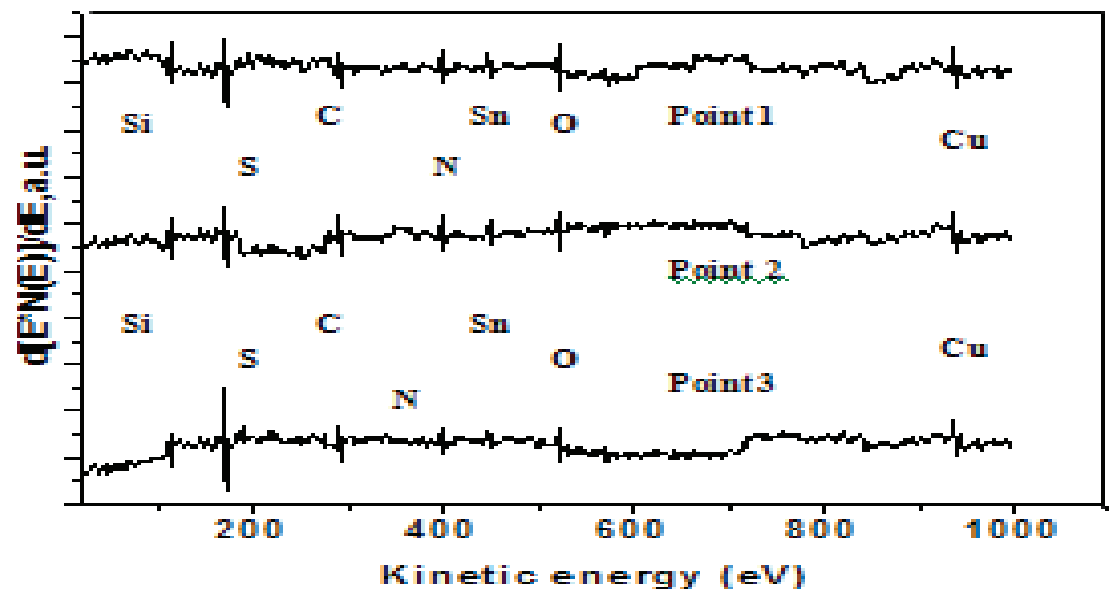

Figure 5. AES analysis of SEM at 10X evaluated in three points of ECC of CS exposed six months at Mexicali 


\begin{tabular}{cccccccccc}
\hline & \multicolumn{3}{c}{ Ensenada } & \multicolumn{3}{c}{ Mexicali } & \multicolumn{3}{c}{ Santa Ana } \\
Elements & Point 1 & Point 2 & Point 3 & Point 1 & Point 2 & Point 3 & Point 1 & Point 2 & Point 3 \\
\hline $\mathrm{C}$ & 10 & 11 & 9 & 10 & 12 & 8 & 10 & 12 & 8 \\
$\mathrm{Cl}$ & Traces & Traces & Traces & 15 & 14 & 12 & 15 & 14 & 12 \\
$\mathrm{Cu}$ & 17 & 16 & 17 & 19 & 18 & 16 & 19 & 18 & 16 \\
$\mathrm{~N}$ & 8 & 10 & 8 & 6 & 8 & 8 & 6 & 8 & 8 \\
$\mathrm{O}$ & 21 & 19 & 18 & 22 & 20 & 17 & 22 & 20 & 17 \\
$\mathrm{~S}$ & 25 & 22 & 29 & 13 & 13 & 21 & 13 & 13 & 21 \\
$\mathrm{Si}$ & 13 & 15 & 13 & 11 & 10 & 11 & 11 & 10 & 11 \\
$\mathrm{Sn}$ & 6 & 7 & 6 & 4 & 5 & 7 & 4 & 5 & 7 \\
\hline
\end{tabular}

Table 7. Atomic concentration (\%) of metallic probes

\begin{tabular}{ccccccc}
\hline Age of CS & \multicolumn{3}{c}{ Mexicali Companies } & \multicolumn{3}{c}{ Tijuana Companies } \\
Years & $\mathbf{1}$ & $\mathbf{2}$ & $\mathbf{3}$ & $\mathbf{1}$ & $\mathbf{2}$ & $\mathbf{3}$ \\
\hline 1 & 23 & 21 & 26 & 20 & 24 & 22 \\
5 & 62 & 66 & 68 & 65 & 69 & 64 \\
10 & 93 & 96 & 98 & 93 & 91 & 94 \\
\hline
\end{tabular}

Table 8. Analysis of corrosion products of CS at: 1,5 and 10 years, $\%$
In the analysis of Auger spectra in Tijuana that is a marine environment, the major air pollutant that reacts with copper surface was the sulphur, that occured in Mexicali. Auger spectra indicate the air pollutants combined with $\mathrm{CO} 2$ of the environment. Table 7 represents the atomic concentration of metallic probes with the percentages of air pollutants and carbon and oxygen.

Other analysis were made to determine by periods of time the damage of the presence of tarnishing or corrosion products in ECC, and depending if the operation efficiency of CS is known, as showed in Table 8, with more presence of the corrosion phenomena when the CS was used more time.

\section{Conclusions}

The miniaturization and the requirement for high component density of small electronic devices need closer spacing and thinner metallic paths affected by corrosion and electrical failures. Copper exposed to air pollutants reveal that an increase on their concentrations at outdoor conditions has a critical impact on the indoor corrosion process in arid and marine environments. $\mathrm{RH}$ values higher than $75 \%$ and concentration of air pollutants, promotes corrosion. New technology with CS used to improve the manufacturing process of the electronics industry in the northwest of Mexico, is an important factor to increase their productive yielding.

The CS are affected by aggressive environments principally sulfurs in Mexicali and chlorides in Tijuana, and decrease their operative efficiency. This study shows the necessity to replace constantly the CS in industrial plans of this region to avoid economical losses. Pitting corrosion was present in winter in both cities and uniform corrosion in summer. The control of the microclimate indoors of the electronics industry is necessary and the constant check of the operative efficiency of CS, to maintain manufacturing processes with excellent conditions.

\section{Discussions}

Corrosion in electronic systems of cars was increased in the last 30 years. In this process galvanic electrochemical cells are formed, which are capable of generating electrical failures. Copper is used in electronic devices and equipments for the manufacturing of electrical connections and connectors, for its good electrical and thermal conductivity.

Microcircuits, electrical connectors and connections of copper are very susceptible to the atmospheric corrosion in both cities mentioned above. Scientists in corrosion and materials consider that a bad operation of electronic systems of cars is due to the presence of corrosion in their unions.

\section{Acknowledgements}

The authors express their gratitude to CETYS for the support with the MatLab software and to the industrial plants of Mexicali and Tijuana for their support to the study, with managerial, engineering and technical people to provide statistical data and technical support. 


\section{References}

Annual Book of ASTM Standards. Wear and Erosion: Metal Corrosion, volume 03.02, 2000.

APA-Assembly Plants Association, Mexicali Goverment, 2010.

ASHRAE Handbook Heating. Ventilating and Ari-Conditioning, Applications, American Society of Heating, Refrigerating and Air-Conditioning Engineers Inc., 1999.

ASTM G91-97. Standard Practice for Monitoring Atmospheric SO2 Using the Sulfation Plate Technique, 2010.

ASTM G140-02. Standard Test Method for Determining Atmospheric Chloride Deposition Rate by Wet Candle Method, 2008.

Balachandran D., Harold W. An Engineer's Guide to MATLAB, 2ed., with Applications Electrical Systems, Prentice Hall, 2005.

Belanger P.R. Control Engineering, Saunders, 1995.

Bishop R.H. Modern Control Systems Analysis and Design Using MATLAB \& SIMULINK, Addison-Wesley, 1997.

Cole S., Paterson D.A. Relation of Atmospheric Pollution and the Generation of Corrosion in Metals of Copper, Steel and Nickel, Corrosion Engineering, 2004.

Dillon P. MTI \& DOE Launch Project Partnerships, Communications Materials Technology Institute of the Chemical Process Industries, Inc, 2000.

Dorf R.C., Bishop R.H. Modern Control Systems, 10th ed., Prentice Hall, 2005.

Goodwin G.C., Graebe S.F., Salgado M.E. Control System Design, Prentice Hall, 2001.

ISO 9223:1992. Corrosion of Metals and Aalloys, Corrosivity of Atmospheres, Classification.

ISO 11844-2:2005. Corrosion of Metals and Alloys-Classification of Low Corrosivity of Indoor Atmospheres-Determination and Estimation Attack in Indoor Atmospheres. ISO, Geneva, 2005.

ISO 11844-1:2006. Corrosion of Metals and Alloys-Classification of Low Corrosivity of Indoor Atmospheres-Determination and Estimation of Indoor Corrosivity. ISO, Geneva, 2006.

King P.J., Mamdani E.H. The Application of Fuzzy Control Systems to Industrial Processes. Automatica, volume 13 (issue 3), May 1977: 235-242.

Kuo B.C. Automatic Control Systems, 7th ed., Prentice-Hall, 1995.

Lewis P.H., Yang C. Basic Control Systems Engineering, Prentice Hall, 1997.

López.-Badilla G. Caracterización de la corrosión en materiales metálicos de la industria electrónica en Mexicali, BC, thesis (Ph.D.), Spanish, 2008.

Lopez B.G., Valdez S.B., Zlatev K.R., Flores P.J., Carrillo B.M., Schorr W.M. Corrosion of Metals at Indoor Conditions in the Electronics Manufacturing Industry. Anti-Corrosion Methods and Materials, 2007.

Lopez G., Tiznado H., Soto G., De la Cruz W., Valdez B., Schorr M., Zlatev R. Corrosion de dispositivos electronicos por con- taminacion atmosferica en intertiores de plantas de ambientes aridos y marinos. Nova Scientia, 2010 (in spanish).

Lopez B.G., Valdez S.B., Schorr W.Mi., Zlatev R., Tiznado V.H., Soto H.G., De la Cruz W. AES in Corrosion of Electronic Devices in Arid in Marine Environments. Anti Corrosion Methods and Materials (in press).

Lopez B.G., Valdez S.B., Schorr W.M., Tiznado V.H., Soto H.G. Influence of Climate Factors on Copper Corrosion in Electronic Equipments and Devices. Anti-Corrosion Methods and Materials, 2010.

Moncmanova A. Environmental Deterioration of Materials, WITPress, 2007, pp. 108-112.

Ogata K. Modern Control Engineering, 4th ed., Prentice-Hall, 2002.

Phillips C.L., Harbor R.D. Feedback Control Systems, 4th ed., Prentice Hall, 2000.

Robertson G., Fenderson K. Use of Control Systems Industrial Activities, Panamerican Editorial, 2005.

Qiang X., Wen-Jian C. Effective Transfer Function Method for Decentralized Control System Design of Multi-Input Multi-Output Processes. Journal of Process Control, volume 16 (issue 8), September 2006: 773-784.

Sankara-Narayanan Y.W.P., Kang-Yong L., Science Direct, Elsevier B.V. Fretting-Corrosion Mapping of Tin-Plated Copper Alloy Contacts, volume 262 (issues 1-2), January 2007: 228-233.

Valdez B., Schorr M. El control de la corrosión en la industria electrónica. Revista Ciencia, 2006 (spanish).

Veleva L., Valdez B., Lopez G., Vargas L., Flores J. Atmospheric Corrosion of Electro-Electronics Metals in Urban Desert Simulated Indoor Environment. Corrosion Engineering Science and Technology, 2008.

Zlatev R., Valdez B., Stoycheva M., Vargas L., Lopez G., Schorr M. Simpsoium 16, NACE, Corrosion and Metallurgy, IMRC 2009, Cancun, Mexico.

\section{Citation for this article:}

\section{Chicago citation style}

López-Badilla,Gustavo, Ángel Vega-Matus, Diego Millán-Arce, José González-Kleyton, Guillermo Conteras-León. Effect of Corrosion in the CS Operation in Indoor of the Electronics Industry in the Northwest of Mexico. Ingeniería Investigación y Tecnología XIII, 04 (2012): 461-472.

\section{ISO 690 citation style}

López-Badilla G., Vega-Matus A., Millán-Arce D., González-Kleyton J., Conteras-León G. Effect of Corrosion in the CS Operation in Indoor of the Electronics Industry in the Northwest of Mexico. Ingeniería Investigación y Tecnología, volumen XIII (número 4), octubre-diciembre 2012: 461-472. 


\section{About the authors}

Gustavo López-Badilla. Was born in Santa Ana, Sonora, in the northwestern of Mexico, he is an Electronics Engineer, MI Systems Engineering, Doctor in Industrial Chemistry and is a Postdoctoral in Physical Chemistry and Surface Analysis (Nanoscience and Nanotechnology Center-UNAM) candidate. He is a member of the National System of Researchers (SNI) in Mexico. Has six years experience in industry and 11 years in Research and Teaching in the basic areas of Mathematics, Physics and Chemistry. Assistance to 20 national and international conferences and 35 extension publications: technical and scientific, in electronic, corrosion, materials, environment and surface analysis and participate in two books. He has won a national award in Materials Congress.

Ángel Vega-Matus. Student of 8th semester of Cybernetic and Electronic Engineering, with two years of experience in industrial plants.

Diego Millán-Arce. Student of 8th semester of Cybernetic and Electronic Engineering, with two years of experience in industrial plants.

José González-Kleyton. Student of 8th semester of Cybernetic and Electronic Engineering, with three years of experience in industrial plants.

Guillermo Contreras-León. Student of 8th semester of Cyberneticand Electronic Engineering, with one year of experience in industrial plants. 